\title{
Gastric and Extragastric GIST Presentation and Management, in a Tertiary Referral Center - A Ten Years Retrospective Cohort Study
}

\author{
Ahmed Abdallah ${ }^{1}$, Mosab Shetiwy ${ }^{1}$, Islam A Elzahaby ${ }^{1}$, Basel Refky ${ }^{1}$, Khaled AbdElwahab ${ }^{1}$, \\ Osama Eldamshety ${ }^{1}$, Mahmoud Abdelaziz ${ }^{1}$, Amr Abouzid ${ }^{1}$, Nirmeen Megahed ${ }^{2}$, Islam H Metwally ${ }^{1 *}$
}

${ }^{1}$ Surgical oncology unit, Oncology center Mansoura University (OCMU), Mansoura, Egypt ${ }^{2}$ Pathology department, Faculty of Medicine, Mansoura University, Mansoura, Egypt

\section{ABSTRACT}

Introduction: Gastrointestinal stromal tumor (GIST) is the commonest mesenchymal tumour of the gut. However, the epidemiology of the disease in Egypt is not adequately studied. Methods: A retrospective cohort study was conducted on patients treated for GIST from June 2008 to April 2018 in a tertiary center. Sixty-two cases were eligible for the study.

Results: The stomach was the commonest tumor site. The incidence of tumor residue was higher in extra-gastric (intestinal) GISTs. Laparoscopy was more frequently used in gastric GIST surgery. Overall survival was affected by the tumor size and age of the patient, while disease free survival was negatively influenced by invasion of surrounding organs necessitating multiorgan resection, presence of distant metastasis, tumor size and sex of the patients.

Conclusion: Gastric and extragastric GIST have a comparable prognosis, however, overall survival and disease free survival are both influenced by defined tumor and patient's characteristics.

Key words: gastric GIST, small bowel GIST, Imatinib

\section{INTRODUCTION}

Gastrointestinal stromal tumors (GISTs) are uncommon tumors that can occur throughout the smooth muscle layer of the gastrointestinal tract (1) or, rarely, from other intra-abdominal soft tissues (2). However, GISTs are the commonest mesenchymal tumors of the alimentary tract, representing $80 \%$ of these tumors (3).

Recently, Soreide et al. (4) analyzed the data of more than 13,550 patients reported in 29 studies from 19 countries and found that most studies reported incidences ranging from 10 to 15 cases per million. There was, however, a variation between results, with highest incidences as 19-22 cases/million reported in Norway (5), China $(6,7)$, Taiwan (8), and Korea (9), while lowest incidences as 4.3 and 5.2 cases/million was reported in the Shanxi province in China (10) and in the Czech republic and Slovakia (11), and $6.8 \mathrm{cases} / \mathrm{million}$ reported in Canada (12) and in the USA (13).
*Corresponding author: Islam H Metwally, MD, MRCS Consultant and lecturer of surgical oncology Oncology Center Mansoura University Egypt

E-mail: drislamhany@mans.edu.eg
Received: 05.02.2020

Accepted: 07.04.2020

Copyright (c) Celsius Publishing House www.sgo-iasgo.com 
Recently, GIST less than $1 \mathrm{~cm}$ in the largest diameter, known as micro GIST (14), have been frequently detected in meticulously examined postoperative specimens following gastric resection (35\%) (15), resection of the gastro-oesophageal junction (10\%) (16) and far less common in surgical specimens of sigmoid colon, vermiform appendix, and rectum $(0.2 \%, 0.1 \%$, and $0.01 \%)$, respectively (17).

In 1909, the Spanish neurohistologist Santiago Raman y Cajal described the cell of origin of the GISTs (18), which was named for him. Agaimy and Wunsch questioned the nature and origin of the extra-gastrointestinal GIST tumors. They thought that they may either be extramural gastrointestinal GISTs or possibly KIT-positive non-GISTs. On the basis of the interstitial cells of Cajal (ICC) theory, it is difficult to explain the occurrence of GISTs at an anatomic site, where the proposed cell of origin (ICCs or myenteric plexus) is not histologically found (19).

However, Yamaura et al. (20) detected the presence of c-KIT positive interstitial cells, which did not stain for methylene blue, surrounding the pancreatic intercalated ducts and acinus. These cells were morphologically and immunophenotypically distinct from other interstitial cells like fibroblasts, fibrocytes, neurons, or any other mesenchymal cells, had phenotypic characteristics of the canonical enteric interstitial cells of Cajal and named pancreatic interstitial Cajal-like cells. Now these interstitial Cajal-like cells are called telocytes (21).

Several risk stratifications have been utilized along the years, which incorporate mitotic count and tumor size alone (22), or with the addition of the primary tumor site $(23,24)$. Other independent risk factors that negatively affect disease-free survival like tumor rupture and incomplete resection should be considered (25).

The aim of surgical resection is to achieve R0 resection if possible, with $\mathrm{R} 1$ resection being acceptable in certain situations. Both RO and R1 resection are associated with a better prognosis than $\mathrm{R} 2$ resection (26).

Lymph node metastasis is uncommon (27). No oncologic benefit could be expected from routine lymphadenectomy during surgical resection of GISTs, however, some peri-lesional lymph nodes could be unintentionally retrieved as part of the surgical specimen.

Many oncology groups (28) agreed on the importance of performing molecular analysis on all tumors searching for PDGFRA D842V mutation or an SDH-deficient or NF-related GIST, in order to avoid unbeneficial adjuvant therapy, due to either proven insensitivity or lower sensitivity in case such mutations are present.

The standard dose of adjuvant Imatinib therapy is $400 \mathrm{mg}$ daily. However, if tolerated, a dose of $800 \mathrm{mg}$ daily is preferred for GIST cases with an exon 9 KIT mutation, as they show relative resistance to adjuvant Imatinib on the standard dose, as detected by data analysis from (ACOSOG) Z9001 trial (29) and supported by reports of many authors (30-32).

\section{MATERIALS AND METHODS}

In this retrospective study, the Institutional Registry of the Oncology Center Mansoura University (OCMU) was thoroughly revised for GIST cases that attended the hospital from June 2008 till April 2018. Sixty-six patients were found. Four patients were excluded for having spindle cell tumours with no positive IHC to confirm GIST diagnosis. The patients were followed-up utill August 2020. The primary aim was to compare the clinico-epidemiologic, pathologic, and management pattern of gastric and extragastric intestinal GISTs. The secondary outcomes were to assess factors affecting overall and disease free survival and to present our experience of rare site GISTs.

\section{Statistical analysis}

Statistical analysis was conducted using SPSS version 22 (Inc, Chicago, IL). Continuous variables were presented as mean when symmetrical or median and range when asymmetrical. Categorical variables were presented as proportions. Univariate analysis was done using Chi-Square test, MannWhitney $\mathrm{U}$ test or Student t-test, as appropriate. Survival analysis was conducted using Kaplan Meier curve and significance determined by log rank test. Significant factors affecting overall and disease free survival were then assessed by multivariate analysis using Cox proportional hazards regression. $P$ value $<0.05$ was considered statistically significant.

\section{RESULTS}

Our study group comprised: 34 cases of gastric (including 2 cases of omental), 20 cases of small intestinal, 3 cases of colonic, 2 cases of pancreatic, 2 cases of rectal and one case ovarian GISTs.

The 54 gastric and intestinal GISTs were included in the statistical analysis, while the rare sites of GISTs were presented separately. 
Table 1 - The IHC staining pattern of GIST cases in our series (between brackets gastric versus extragastric GISTs)

\begin{tabular}{lcccc}
\hline & CD117 & CD34 & DOG1 & S100 \\
\hline Negative & $2(1 / 1)$ & $5(2 / 3)$ & 0 & $11(7 / 4)$ \\
\hline Diffuse positive & $44(26 / 18)$ & $17(13 / 4)$ & $19(14 / 5)$ & $1(1 / 0)$ \\
\hline Focal positive & $4(3 / 1)$ & $6(3 / 3)$ & 0 & $3(2 / 1)$ \\
\hline
\end{tabular}

\section{Epidemiology}

Mean age at diagnosis was $53.46( \pm 13.26), 53.7 \%$ were females while the rest were males. Six cases $(12 \%)$ were incidentally discovered, $59.3 \%$ of patients presented with pain, $18 \%$ with abdominal mass, and $3.7 \%$ with weight loss. Most patients (77.8\%) did not complain of gastrointestinal bleeding. Commonest tumor location in the stomach was the greater curvature, in about a third of cases (10/34 patients), while the commonest location in the small intestine was the ileum (12/20 patients) with one patient presenting the GIST in Meckel's diverticulum as previously reported (33). Multiple tumors were found in 3 cases ( 1 case of gastric and 2 cases of intestinal GISTs).

Median tumor size according to the radiological assessment was $10 \mathrm{~cm}$ (ranging from 1.2 to 35). In about a fifth of the cases $(20.4 \%)$ there was radiological invasion of other organs; the commonest invasion site was the liver ( 7 cases), followed by pancreas ( 2 cases), the diaphragm (1 case) and both liver and pancreas (1 case). Adjacent organ invasion was more frequent in gastric GISTs. Distant metastasis was rare, occurring in
$13 \%$ of cases. Exploration was done in $88.9 \%$ of patients. Six patients ( 5 with gastric and 1 with intestinal GISTs) died during a median follow up of 25 months.

\section{Pathology}

The most common histological variant was spindle cells $(57.4 \%)$, followed by mixed cells $(16.7 \%)$ and lastly epithelioid cells GIST (11.1\%). According to National institute of health (NIH) consensus classification criteria for defining risk of aggressive clinical course of primary GISTs (34) $44.4 \%$ of cases were of high, $22.2 \%$ were of intermediate and $14.8 \%$ were of low risk status. Median size on pathology was $9 \mathrm{~cm}$ (ranging from 3 to $50 \mathrm{~cm}$ ). Incomplete resection (R1 and R2) were encountered in 9 cases.

Common IHC panel for both gastric and extra-gastric (intestinal) GISTs is displayed in table 1.

\section{Treatment (fig. 1)}

Thirteen cases received neoadjuvant Imatinib (Gleevec ${ }^{\circledR}$ ) therapy with seven cases (five cases of gastric and two cases of intestinal GISTs) showing

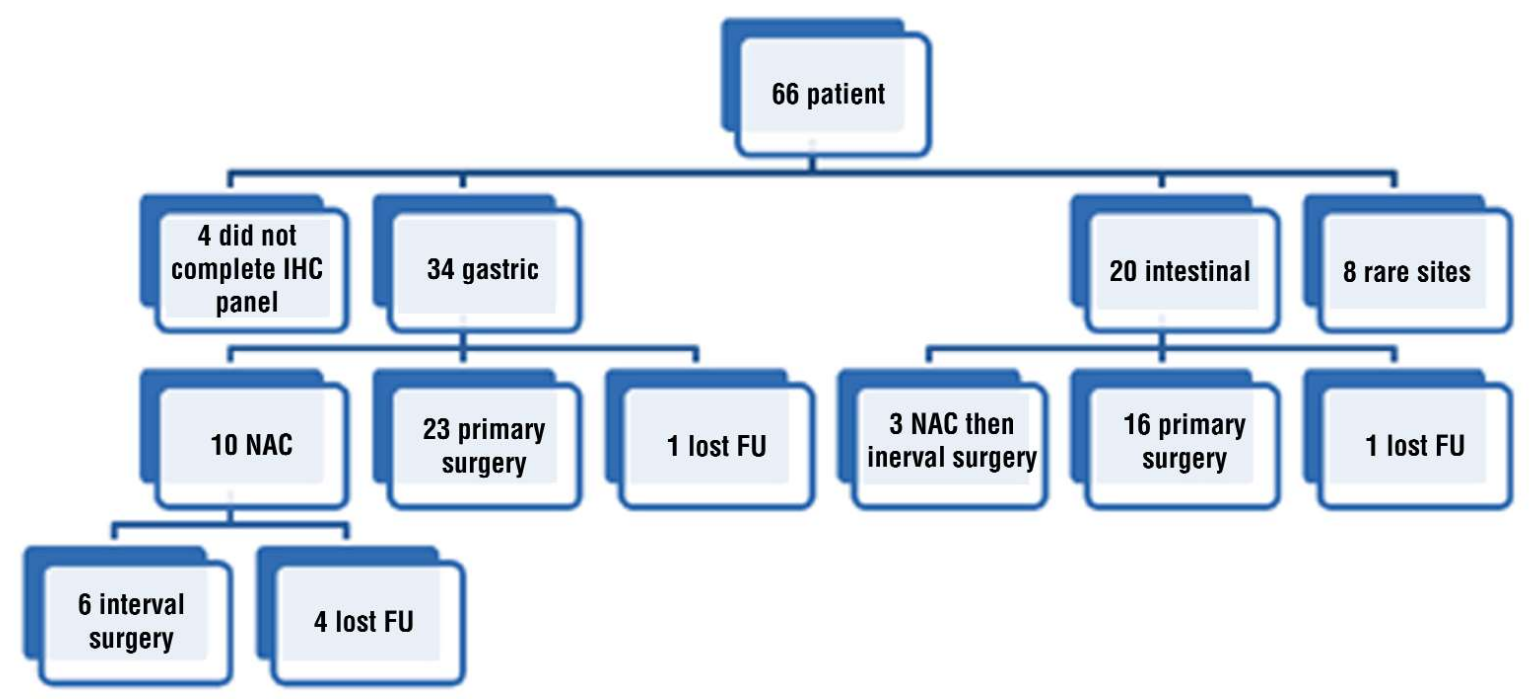

Figure 1 - A flowchart of patients recruited in the study, including their treatment (IHC; immune-histochemistry, NAC; neoadjuvant chemotherapy, FU; follow up) 


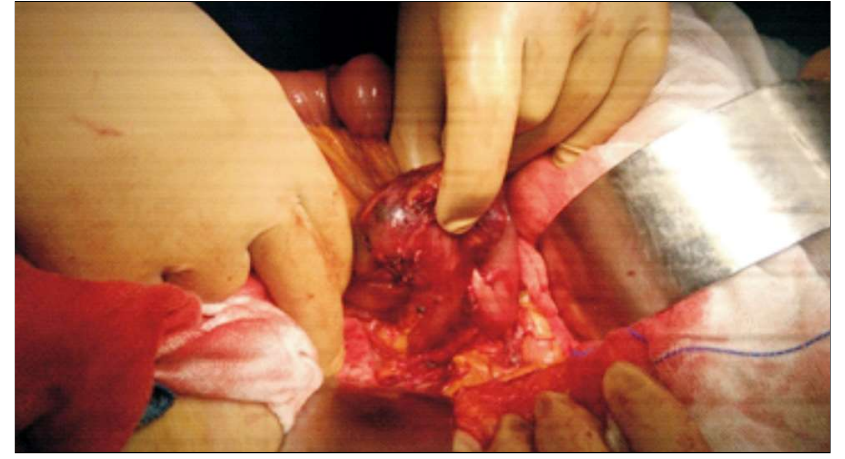

Figure 2 - Intra-operative aspect of GIST at the proximal jejunum close to DJ junction

significant regression up to tumor disappearance in one case with gastric GIST. However, the response was not maintained in one patient who did not undergo surgery due to poor performance status and in another patient, who continued for longer time on Imatinib as per-panel decision. Nineteen patients with gastric GISTs underwent sleeve gastrectomy, four patients underwent anatomical resection (two cases with proximal, and two cases with distal gastrectomy), another four patients underwent wider excision of body mass and one patient with small tumor underwent open transmucosal enucleation. One patient with cystic gastric GIST was misdiagnosed as pseudocyst and treated initially with cystogastrostomy which was complicated with increased hematemesis and required re-operation after short Imatinib course, with sleeve gastrectomy. On the other hand, the most common surgery for small intestinal GIST was segmental resection in thirteen cases, wedge resection in four cases (fig. 2), pylorus preserving pancreaticoduodenectomy and right hemicolectomy in one case, respectively. Laparoscopic/ assisted resection was performed only in ten cases, representing $20.8 \%$ of those who underwent surgery - all of them gastric GISTs. Multi-organ resection was required in eight cases; the most common was splenectomy (three cases), then splenectomy and distal pancreatectomy (two cases), partial cystectomy (two cases) and segmental colectomy (one case). Adjuvant Imatinib therapy (400 mg daily) was used in twenty-six cases, subsequent to panel decision.

\section{Comparison of gastric to extragastric (intestinal) GIST (table 2)}

In the current study, gastric GISTs were significantly different from intestinal GISTs in terms of more invasion to surrounding organs, more laparoscopic management, less R2 resection and receiving of less adjuvant therapy. However, neither overall nor disease free survival were significantly different between the two groups.

Table 2 - Comparison of patient and tumor characteristics between gastric and intestinal GISTS

\begin{tabular}{|c|c|c|c|}
\hline Variable & $\begin{array}{r}\text { Gastric } \\
\text { (34 patients) }\end{array}$ & $\begin{array}{r}\text { Intestinal } \\
\text { (20 patients) }\end{array}$ & P-value \\
\hline Age (Mean +/-SD) & $53.35(+/-14.2)$ & $53.65(+/-11.9)$ & .94 \\
\hline $\operatorname{Sex}(\mathrm{F} / \mathrm{M})$ & $19 / 15$ & $10 / 10$ & .67 \\
\hline Size on radiology (Median and range) & $10(2.5-28)$ & $10(1.2-35)$ & .82 \\
\hline $\begin{array}{l}\text { Radiologic invasion of surroundings } \\
\text { (Liver/Pancreas/Both/Diaphragm) }\end{array}$ & $\begin{array}{r}10 \\
6 / 2 / 1 / 1\end{array}$ & $\begin{array}{r}1 \\
1 / 0 / 0 / 0\end{array}$ & .016 \\
\hline $\begin{array}{l}\text { Distant Metastatsis } \\
\text { (Liver/Peritoneum/Both/Lung) }\end{array}$ & $\begin{array}{r}4 \\
1 / 1 / 1 / 1\end{array}$ & $\begin{array}{r}3 \\
3 / 0 / 0 / 0\end{array}$ & .87 \\
\hline Size on pathology (Median and range) & $9.5(3-30)$ & $9(4-50)$ & .63 \\
\hline Neoadjuvant & 10 & 3 & .27 \\
\hline Laparoscopic/assisted resection & $9 / 1$ & 0 & .016 \\
\hline Multi-organ resection & 5 & 3 & .89 \\
\hline Residual tumor & $5 \mathrm{R} 1$ & $4 \mathrm{R} 2$ & .01 \\
\hline Morphologic type (Spindle/Epithelioid/Mixed) & $19 / 2 / 6$ & $12 / 4 / 3$ & .38 \\
\hline Risk status (High/Intermediate/Low) & $14 / 7 / 5$ & $10 / 5 / 3$ & .98 \\
\hline Adjuvant therapy & 14 & 12 & .025 \\
\hline Recurrence & 8 & 9 & .22 \\
\hline Site of recurrence (Local/Liver/Peritoneum/Bone/Mixed) & $3 / 2 / 0 / 0 / 3$ & $1 / 1 / 2 / 1 / 4$ & .31 \\
\hline Mean overall survival & 88.61 & 106.59 & .23 \\
\hline Mean disease-free survival & 62.55 & 52.31 & .51 \\
\hline
\end{tabular}



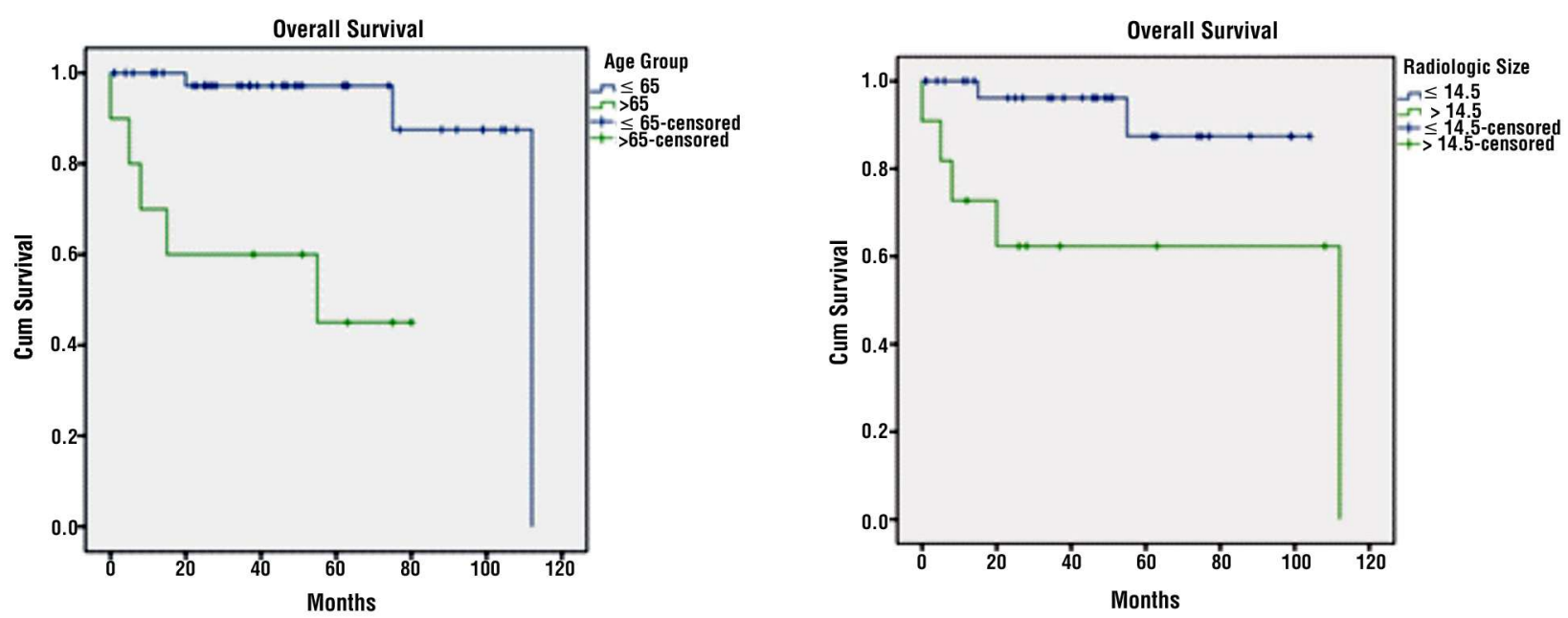

Figure 3 - Kaplan Meier curves of the different factors significantly affecting the overall survival

\section{Overall survival}

The mean overall survival (OAS) was 96.28 months. Age $\geq 65$ years old ( $P$-value $\leq 0.001$ ) and radiologic size larger than $14.5 \mathrm{~cm}(\mathrm{P}$-value $=0.011)$ were associated with shorter survival (fig. 3). After multivariate analysis using Cox regression the only independent prognostic factor for survival was the age $>65$ years old with P-value $0.008(\mathrm{HR}=18.7) \mathrm{Cl} 95 \%$ 2.2-163.2 (table 3).

Table 3 - Univariate and multivariate analysis of factors affecting the overall survival (OAS)

\begin{tabular}{|c|c|c|c|c|}
\hline \multirow{2}{*}{$\overline{\text { Variable }}$} & \multicolumn{2}{|c|}{ Univariate analysis } & \multicolumn{2}{|c|}{ Multivariate analysis } \\
\hline & Estimated mean OAS & P-value & HR (95\%CI) & Significance \\
\hline Gender & & .14 & & \\
\hline Male & 100.5 & & & \\
\hline Female & 89.76 & & & \\
\hline Age & & $<.001$ & $18.7(2.1-163)$ & .008 \\
\hline$\leq 65$ & 105.85 & & & \\
\hline$>65$ & 47.05 & & & \\
\hline Radiologic size & & .011 & $5.3(0.9-29)$ & .059 \\
\hline$\leq 14.5$ & 96.29 & & & \\
\hline$>14.5$ & 73.08 & & & \\
\hline Invasion & & .62 & & \\
\hline No & 95.02 & & & \\
\hline Yes & 94.11 & & & \\
\hline Distant metastasis & & .3 & & \\
\hline Neoadjuvant therapy & & .5 & & \\
\hline No & 97.67 & & & \\
\hline Yes & 63.31 & & & \\
\hline Operative approach & & .87 & & \\
\hline Open & 97.12 & & & \\
\hline Laparoscopic & 56.12 & & & \\
\hline Visceral resection & & .22 & & \\
\hline No & 100.13 & & & \\
\hline Yes & 80.06 & & & \\
\hline Residue & & .33 & & \\
\hline No & 98.04 & & & \\
\hline Yes & 77.97 & & & \\
\hline Multiplicity & & .52 & & \\
\hline Pathologic morphology & & .34 & & \\
\hline Mitotic figure & & .84 & & \\
\hline Risk status & & .59 & & \\
\hline Adjuvant therapy & & .098 & & \\
\hline
\end{tabular}




\section{Disease free survival}

The estimated mean disease-free survival (DFS) was 58.37 months. Male sex, radiologic size $>14.5 \mathrm{~cm}$, presence of distant metastasis and invasion of surrounding organs necessitating multi-organ resection were the negative prognostic factors, P-value $=0.021$, $0.006,0.018$ and 0.029 respectively (fig. 4). In the multivariate analysis, none of the variables were independent predictors of DFS (table 4).

\section{Recurrence pattern}

Recurrence occurred in seventeen cases; in about third of them (six cases) it was both local and distant. The recurrence was higher in cases with intestinal GISTs, although non-significant statistically. Eight of the recurrent cases underwent re-exploration, half of them (four cases) developed second recurrence, and two were re-explored.

\section{Rare sites GIST}

In the current study, two females and one male with colonic GIST were encountered and their data is displayed in table 5.

Also, two cases of pancreatic GIST were registered (table 6), one of them was a part of neurofibromatosis type I syndrome with multiple disease foci (fig. 5).

Moreover, two cases with rectal and one case with ovarian GIST were previously reported $(35,36)$.

\section{DISCUSSION}

Most GISTs occur on a sporadic basis, but some occur in the context of clinical syndromes. The most
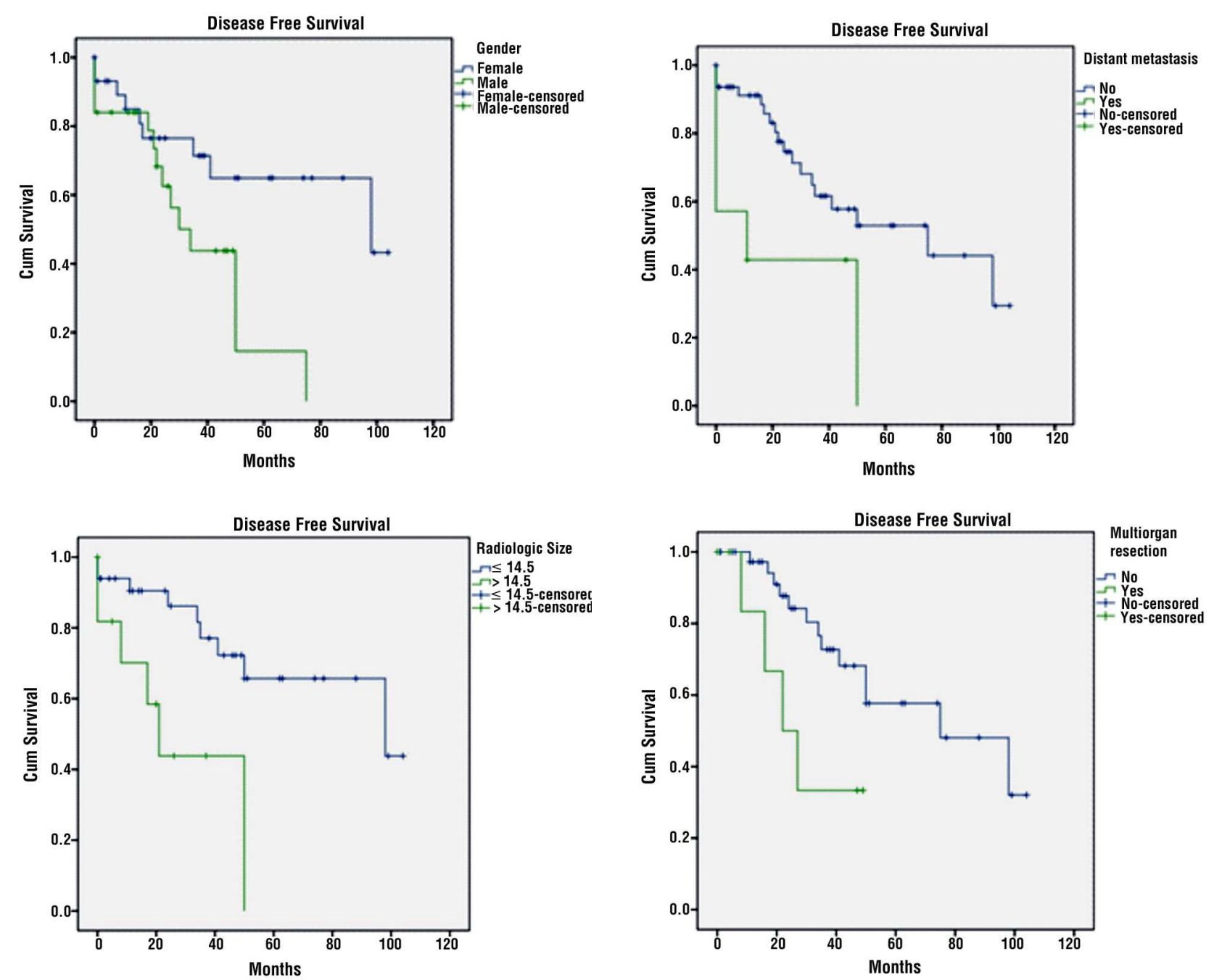

Figure 4 - Kaplan Meier curves of the different factors significantly affecting the disease free survival 
Table 4 - Univariate and multivariate analysis of factors affecting the disease free survival

\begin{tabular}{|c|c|c|c|c|}
\hline \multirow{2}{*}{$\begin{array}{l}\text { Multivariate analysis } \\
\text { Variable }\end{array}$} & \multicolumn{3}{|c|}{ Univariate analysis } & \multirow[b]{2}{*}{ Significance } \\
\hline & Estimated mean DFS & P-value & HR (95\% Cl) & \\
\hline $\begin{array}{c}\text { Gender } \\
\text { Female } \\
\text { Male }\end{array}$ & $\begin{array}{l}72.83 \\
35.86\end{array}$ & .021 & $1.4(0.29-7)$ & .66 \\
\hline $\begin{array}{l}\text { Age } \\
\quad \leq 65 \\
>65\end{array}$ & $\begin{array}{l}61.58 \\
33.33\end{array}$ & .33 & & \\
\hline $\begin{array}{c}\text { Radiologic size } \\
\leq 14.5 \\
>14.5\end{array}$ & $\begin{array}{l}76.82 \\
27.91\end{array}$ & .006 & $4.7(0.99-22)$ & .052 \\
\hline $\begin{array}{c}\text { Invasion } \\
\text { No } \\
\text { Yes }\end{array}$ & $\begin{array}{l}56.55 \\
71.18\end{array}$ & .15 & & \\
\hline $\begin{array}{l}\text { Distant metastasis } \\
\text { No } \\
\text { Yes }\end{array}$ & $\begin{array}{c}63.18 \\
23\end{array}$ & .018 & $0.84(0.01-7)$ & .87 \\
\hline $\begin{array}{l}\text { Neoadjuvant therapy } \\
\text { No } \\
\text { Yes }\end{array}$ & $\begin{array}{l}60.66 \\
31.85\end{array}$ & .51 & & \\
\hline $\begin{array}{l}\text { Operative approach } \\
\text { Open } \\
\text { Laparoscopic }\end{array}$ & $\begin{array}{c}64.55 \\
49\end{array}$ & .68 & & \\
\hline $\begin{array}{l}\text { Visceral resection } \\
\text { No } \\
\text { Yes }\end{array}$ & $\begin{array}{c}70.09 \\
28.5\end{array}$ & .029 & $1.7(0.16-18)$ & .67 \\
\hline $\begin{array}{c}\text { Residue } \\
\text { No } \\
\text { Yes }\end{array}$ & $\begin{array}{l}63.04 \\
82.33\end{array}$ & .23 & & \\
\hline $\begin{array}{c}\text { Multiplicity } \\
\text { No } \\
\text { Yes }\end{array}$ & $\begin{array}{c}61.55 \\
38\end{array}$ & .54 & & \\
\hline $\begin{array}{l}\text { Pathologic morphology } \\
\text { Spindle } \\
\text { Epithelioid } \\
\text { Mixed }\end{array}$ & $\begin{array}{l}72.91 \\
51.56 \\
39.86\end{array}$ & .17 & & \\
\hline $\begin{array}{l}\text { Mitotic figure } \\
\quad<5 \\
5-10 \\
>10\end{array}$ & $\begin{array}{c}78.22 \\
59.19 \\
30\end{array}$ & .18 & & \\
\hline $\begin{array}{l}\text { Risk status } \\
\text { Low } \\
\text { Intermediate } \\
\text { High }\end{array}$ & $\begin{array}{l}64.83 \\
45.05 \\
56.28\end{array}$ & .26 & & \\
\hline $\begin{array}{l}\text { Adjuvant therapy } \\
\text { No } \\
\text { Yes }\end{array}$ & $\begin{array}{l}50.62 \\
64.49\end{array}$ & .41 & & \\
\hline
\end{tabular}

common of these is neurofibromatosis type 1 , in which GISTs usually occur in small intestine, often as multiple, clinically indolent tumors. Familial GISTs are based on hereditary KIT/ PDGFRA-activating mutations. Pediatric GISTs (almost all gastric) are linked with loss of succinate dehydrogenase subunit B (SDHB), Carney triad and Carney-Stratakis syndromes, the latter being an autosomal dominant syndrome combining GIST and paraganglioma (2). In the current study, only one patient was syndromic, and no pediatric cases were registred.

GISTs are more common in the stomach (50-60\%) and in the small intestine (30-35\%), while less frequent in the colon and rectum (5\%) and the oesophagus $(<1 \%)(37)$. This is concordant with our study's results.

It is still unknown whether EGISTs are lesions detached from their gastrointestinal origin or are metastases from an unknown primary tumor (37). In this series, two cases were omental with no detected attachment with the gut and one was ovarian with obscure origin.

In our series, CD117 was positive in $96 \%$, CD34 was positive in $82 \%$, DOG was positive in $100 \%$, and S100 was positive in $26.7 \%$ of the cases. As mentioned in the 

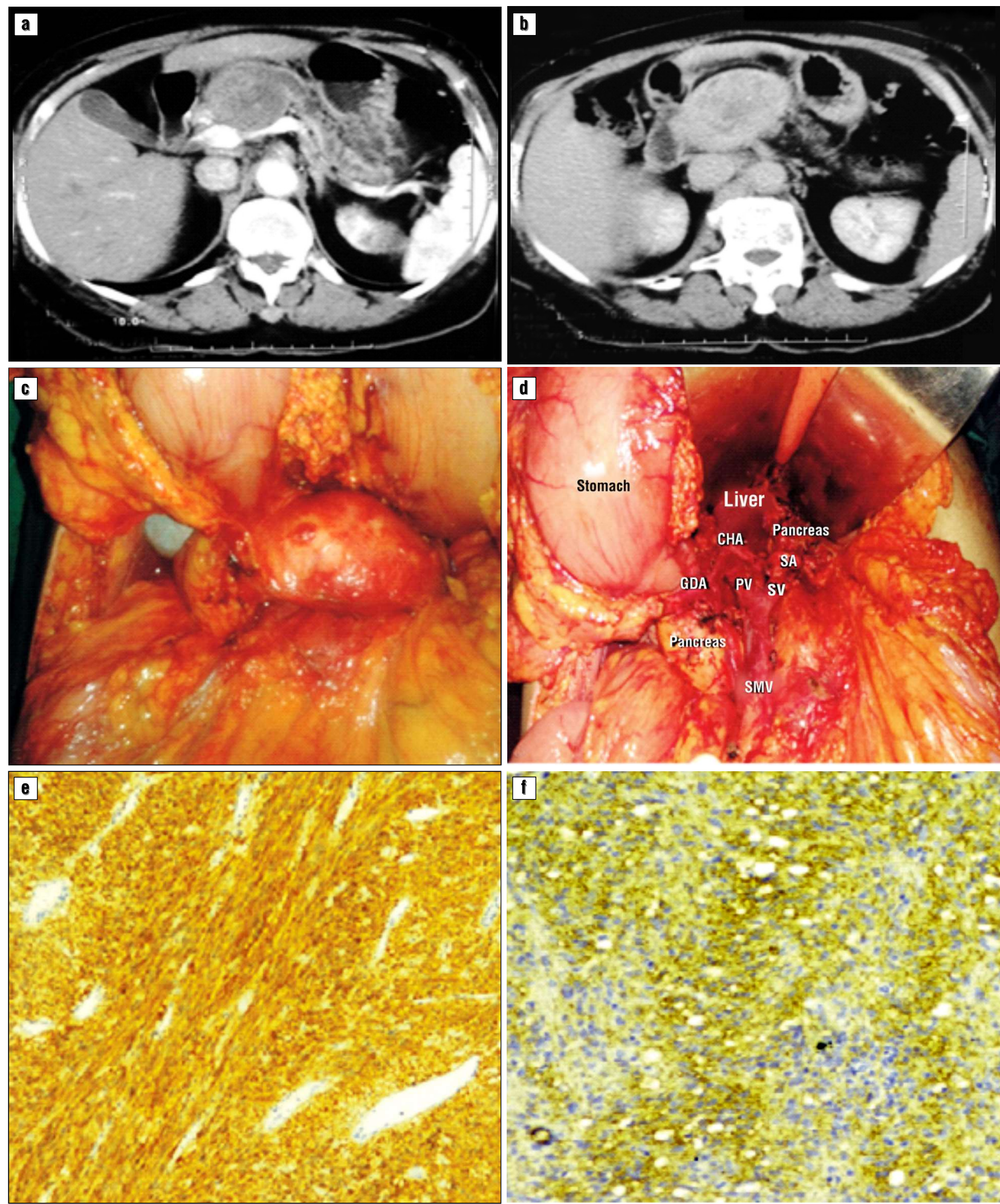

Figure 5 - (a) and (b) CT of pancreatic GIST patient with large heterogenous mass in the pancreatic body displacing the stomach. (c) Intra-operative photo showing large mass adherent to stomach and overlying portal vein. (d) Intra-operative photo showing the operative bed following central pancreatectomy with safety margins obtained. (e) Pathology showing strong diffuse positive memberanous and cytoplasmic staining for CD117. (f) Pathology showing positive memberanous and cytoplamic staining for D0G1

literature, Kit or CD117 is positive in the vast majority (95\%) of GISTs by IHC, whereas only a minor subset (5\%) show low or negative expression of KIT. DOG1, that is also known as ANO1, is constantly positive in GISTs, irrespective of the KIT expression level, supporting the diagnosis of GIST $(22,38)$. 
Table 5 - The patient's characteristics and treatment of the 3 colonic GIST cases

\begin{tabular}{|c|c|c|c|}
\hline & Case 1 & Case 2 & Case 3 \\
\hline Gender & Female & Female & Male \\
\hline Age & 64 years & 57 years & 68 years \\
\hline Presentation & Pain \& diarrhea & Mass \& pain & // \\
\hline Site & Transverse & Caecum & Transverse \\
\hline Primary treatment & Rt hemicolectomy & Rt hemicolectomy & Rt hemicolectomy \\
\hline Adjuvant therapy & Yes & No & No \\
\hline Size & $6 \mathrm{~cm}$ & $9.5 \mathrm{~cm}$ & $2 \mathrm{~cm}$ \\
\hline Risk status & High & Intermediate & Very low \\
\hline Pathologic variant & Epithelioid & Epithelioid & Epithelioid \\
\hline Association & No & No & $\begin{array}{l}\text { Locally advanced colonic } \\
\text { adenocarcinoma }\end{array}$ \\
\hline Recurrence & Yes (liver) after 10 months & No & No \\
\hline Follow up & 2.5 years & 10 years & 1 year \\
\hline
\end{tabular}

Table 6 - The patient's characteristics and treatment of the 2 pancreatic GIST cases

\begin{tabular}{lll}
\hline & Case 1 & Case 2 \\
\hline Gender & Female & Male \\
\hline Age & 74 years & 49 years \\
\hline Presentation & DM & Pain \\
\hline Site & Body and neck & Head \\
Syndromatic & No & NF type I \\
\hdashline Primary treatment & Central pancreatectomy & Whipple \\
\hline Size & $10 \mathrm{~cm}$ & $4 \mathrm{~cm}$ \\
\hline Risk status & High & Low \\
\hdashline Pathologic variant & Mixed & Spindle \\
\hline Adjuvant therapy & Yes & Yes \\
\hdashline Recurrence & No & No \\
Follow up period & 2 years & 1.5 years \\
\hline
\end{tabular}

A laparoscopic approach is clearly discouraged in patients who have large tumours, because of the risk of tumor rupture, which is associated with a very high risk of relapse, as mentioned in the ESMO guidelines for GIST in 2014 (28). In the present series, laparoscopy was the primary modality in managing many cases of gastric GIST following the same oncological rules as in open surgery: gentle handling of the tumor to avoid undesired capsule rupture, aiming for RO resection and using Endobag ${ }^{\circledR}$ (Covidien, MA, USA) to protect from possible capsular tear or seedling while extracting the surgical specimen.

Although primary GISTs may demonstrate inflammatory adhesions to surrounding organs, true invasion is not frequent (26). This in concordance with our series results, where only eight patients required multiorgan resection, although, in eleven patients radiologic invasion of surrounding organs was suspected.

The ultimate significance of an R1 resection for GIST is controversial, as some investigators have found it to be a significant prognostic indicator of overall outcome (39-41), while others have failed to find any significance in terms of recurrence, free or overall survival $(1,42$, 43). In the present study, neither R1 nor R2 were statistically significant predictors of recurrence; however, R2 was more frequently encountered in extragastric cases.

In concordance to other studies comparing gastric and extra-gastric GISTs, the recurrence rate of EGISTs were more frequent, however not statistically significant (44); the overall survival was not significantly worse in our study, in EGISTs.

To the best of our knowledge, the largest reported resected GIST diameter was $40 \mathrm{~cm}$ (45); however, in this series, we encountered a patient with $50 \mathrm{~cm}$ tumor in the ileum treated with segmental intestinal resection and adjuvant therapy. We should emphasize that distant metastases from GISTs were uncommon, encountered only in $13 \%$ of the presented cases, in addition nodal disease was not encountered.

Overall survival in this study was about 96 months, 
which is similar to that reported by other series in Egypt $(46,47)$. In the current study, similar to the previous study from upper Egypt, neither sex, nor histopathologic type affected overall survival (48). In contrast, the age of the patient and the tumor size were the only statistically significant determinants of survival.

In a recent paper the tumor site, size, mitotic index, rupture, and presentation with $\mathrm{Gl}$ bleeding were independent indicators for GIST patients' recurrencefree survival (RFS) (49). However, male sex, larger size, presence of distant metastasis and multi-organ resection were also statistically significant determinants of shorter DFS in this series.

On the other hand, colonic GISTs are rare, as we could identify only three cases during the ten years study period. Surprisingly, all were right sided, epithelioid variant tumours. Amato (50) stated that anatomical resection is not required for colonic GISTs, as such segmental colectomy is the standard approach and mesocolic resection is unnecessary. The three reported cases in our series were treated with formal right hemicolectomy, probably because they were preoperatively diagnosed as carcinomas. Moreover, in this series, we report a case of concomitant colonic adenocarcinoma and GIST; this coincidence was previously recognized in $0.03 \%$ of cases in one study (51).

With regard to pancreatic GISTs, Zhen et al (52) in their study had reviewed 45 cases reported on Pubmed and suggested a worse prognosis in these cases. We herein present two cases of pancreatic GIST with reasonable disease free survival.

\section{Study limitations}

We acknowledge the retrospective nature of our study including only a relatively small number of patients.

\section{CONCLUSION}

At least $2 \beta$ of GISTs cases occur in the stomach. In our series GISTs overall survival was excellent, while the invasion of adjacent organs, large size, distant spread and male sex were negative predictors of disease-free survival. Extragastric GISTs are associated with significantly more frequent residual tumor gross residue after surgery, disease-free survival was not significantly different in comparison to gastric GISTs. In our series in non-intestinal GISTs tumours, results after surgical resection and adjuvant Imatinib was promising.

\section{Ethical approval}

The study was approved by the Ethics Committee of the Faculty of Medicine, University of Mansura, Egypt, under the approval number R/17.11.86

\section{Conflict of interest}

The authors (AA, MS, IAZ, BR, KA, OD, MA, AAZ, NM, IHM) declare that they have no conflict of interest.

\section{REFERENCES}

1. DeMatteo RP, Lewis JJ, Leung D, Mudan SS, Woodruff JM, Brennan MF. Two hundred gastrointestinal stromal tumors: recurrence patterns and prognostic factors for survival. Annals of surgery. 2000;231(1):51-8.

2. Miettinen M, Lasota J. Histopathology of gastrointestinal stromal tumor. Journal of surgical oncology. 2011:104(8):865-73.

3. Steigen SE, Eide TJ. Gastrointestinal stromal tumors (GISTs): a review. APMIS. 2009:117(2):73-86

4. Soreide K, Sandvik OM, Soreide JA, Giljaca V, Jureckova A, Bulusu VR. Global epidemiology of gastrointestinal stromal tumours (GIST): A systematic review of population-based cohort studies. Cancer epidemiology. 2016;40:39-46.

5. Steigen SE, Eide TJ. Trends in incidence and survival of mesenchymal neoplasm of the digestive tract within a defined population of Northern Norway. APMIS. 2006;114(3):192-200.

6. Chan KH, Chan CW, Chow WH, Kwan WK, Kong CK, Mak KF, et al. Gastrointestinal stromal tumors in a cohort of Chinese patients in Hong Kong. World Journal of Gastroenterology: WJG. 2006; 12(14):2223-8.

7. Lv M, Wu C, Zheng Y, Zhao N. Incidence and Survival Analysis of Gastrointestinal Stromal Tumors in Shanghai: A Population-Based Study from 2001 to 2010. Gastroenterology Research and Practice. 2014:2014:834136.

8. Chiang NJ, Chen LT, Tsai CR, Chang JS. The epidemiology of gastrointestinal stromal tumors in Taiwan, 1998-2008: a nation-wide cancer registry-based study. BMC Cancer. 2014;14:102.

9. Cho M-Y, Sohn JH, Kim JM, Kim K-M, Park YS, Kim WH, et al. Current Trends in the Epidemiological and Pathological Characteristics of Gastrointestinal Stromal Tumors in Korea, 20032004. J Korean Med Sci. 2010;25(6):853-62.

10. Wang ZH, Liang XB, Wang Y, Ma GL, Qu YQ, Tian XW. Epidemiology survey of gastrointestinal stromal tumor in Shanxi Province in 2011. Zhonghua yi xue za zhi. 2013;93(32):2541-4

11. Brabec P, Sufliarsky J, Linke Z, Plank L, Mrhalova M, Pavlik T, et al. A whole population study of gastrointestinal stromal tumors in the Czech Republic and Slovakia. Neoplasma. 2009;56(5):459-64.

12. Yan BM, Kaplan GG, Urbanski S, Nash CL, Beck PL. Epidemiology of Gastrointestinal Stromal Tumors in a Defined Canadian Health Region: A Population-Based Study. International Journal of Surgical Pathology. 2008;16(3):241-50.

13. Tran T, Davila JA, El-Serag HB. The Epidemiology of Malignant Gastrointestinal Stromal Tumors: An Analysis of 1,458 Cases from 1992 to 2000. The American Journal Of Gastroenterology. 2005;100:162

14. Mikami T, Terada T, Nakamura K, Okayasu I. The gastric hypercellular microleiomyoma as a precursor lesion for clinical gastrointestinal stromal tumors. Human pathology. 1997:28(12):1355-60.

15. Kawanowa K, Sakuma Y, Sakurai S, Hishima T, Iwasaki Y, Saito K, et al. High incidence of microscopic gastrointestinal stromal tumors in the stomach. Human pathology. 2006;37(12):1527-35.

16. Abraham SC, Krasinskas AM, Hofstetter WL, Swisher SG, Wu TT. "Seedling" mesenchymal tumors (gastrointestinal stromal tumors and leiomyomas) are common incidental tumors of the esopha- 
gogastric junction. The American journal of surgical pathology 2007;31(11):1629-35.

17. Agaimy A, Wunsch PH, Dirnhofer S, Bihl MP, Terracciano LM, Tornillo L. Microscopic gastrointestinal stromal tumors in esophageal and intestinal surgical resection specimens: a clinicopathologic, immunohistochemical, and molecular study of 19 lesions. The American journal of surgical pathology. 2008;32(6): 867-73.

18. Ramon Y Cajal S. Histologie du systeme nerveux de l'homme \& des vertebres. Paris:Maloine; 1909.

19. Agaimy A, Wunsch PH. Gastrointestinal stromal tumours: a regular origin in the muscularis propria, but an extremely diverse gross presentation. A review of 200 cases to critically re-evaluate the concept of so-called extra-gastrointestinal stromal tumours Langenbeck's archives of surgery. 2006;391(4):322-9.

20. Yamaura K, Kato K, Miyazawa M, Haba Y, Muramatsu A, Miyata K, et al. Stromal tumor of the pancreas with expression of c-kit protein: Report of a case. Journal of Gastroenterology and Hepatology. 2004:19(4):467-70.

21. Padhi S, Sarangi R, Mallick S. Pancreatic extragastrointestinal stromal tumors, interstitial Cajal like cells, and telocytes. JOP : Journal of the pancreas. 2013;14(1):1-14.

22. Fletcher CD, Berman JJ, Corless C, Gorstein F, Lasota J, Longley BJ, et al. Diagnosis of gastrointestinal stromal tumors: A consensus approach. Human pathology. 2002;33(5):459-65.

23. Miettinen M, Lasota J. Gastrointestinal stromal tumors: pathology and prognosis at different sites. Seminars in diagnostic pathology. 2006;23(2):70-83.

24. Joensuu H. Risk stratification of patients diagnosed with gastrointestinal stromal tumor. Human pathology. 2008;39(10):1411-9.

25. Joensuu H, Eriksson M, Hall KS, Hartmann JT, Pink D, Schutte J, et al. Risk factors for gastrointestinal stromal tumor recurrence in patients treated with adjuvant imatinib. Cancer. 2014;120(15):2325-33.

26. McCarter MD, Antonescu CR, Ballman KV, Maki RG, Pisters PW, Demetri GD, et al. Microscopically positive margins for primary gastrointestinal stromal tumors: analysis of risk factors and tumo recurrence. J Am Colleg Surg. 2012;215(1):53-9; discussion 9-60.

27. Miettinen M, Furlong M, Sarlomo-Rikala M, Burke A, Sobin LH, Lasota J. Gastrointestinal stromal tumors, intramural leiomyomas, and leiomyosarcomas in the rectum and anus: a clinicopathologic, immunohistochemical, and molecular genetic study of 144 cases. The American journal of surgical pathology. 2001;25(9):1121-33.

28. Gastrointestinal stromal tumours: ESMO Clinical Practice Guidelines for diagnosis, treatment and follow-upt. Annals of Oncology. 2014-25(suppl 3):iii21-iii6.

29. Dematteo RP, Ballman KV, Antonescu CR, Maki RG, Pisters PW, Demetri GD, et al. Adjuvant imatinib mesylate after resection of localised, primary gastrointestinal stromal tumour: a randomised, double-blind, placebo-controlled trial. Lancet (London, England) 2009;373(9669):1097-104

30. Debiec-Rychter M, Sciot R, Le Cesne A, Schlemmer M, Hohenberger $\mathrm{P}$, van Oosterom AT, et al. KIT mutations and dose selection for imatinib in patients with advanced gastrointestinal stromal tumours. European journal of cancer (Oxford, England: 1990). 2006;42(8): 1093-103.

31. Heinrich MC, Owzar K, Corless CL, Hollis D, Borden EC, Fletcher $\mathrm{CD}$, et al. Correlation of kinase genotype and clinical outcome in the North American Intergroup Phase III Trial of imatinib mesylate for treatment of advanced gastrointestinal stromal tumor: CALGB 150105 Study by Cancer and Leukemia Group B and Southwest Oncology Group. Journal of clinical oncology: official journal of the American Society of Clinical Oncology. 2008;26(33):5360-7.

32. Heinrich MC, Corless CL, Demetri GD, Blanke CD, von Mehren M, Joensuu $\mathrm{H}$, et al. Kinase mutations and imatinib response in patients with metastatic gastrointestinal stromal tumor. Journal of clinical oncology: official journal of the American Society of Clinical Oncology. 2003;21(23):4342-9.

33. Metwally IH, Elalfy AF, Awny S, Megahed N. Meckel's diverticulum complicated with gastro-intestinal stromal tumor: Case report
Journal of the Egyptian National Cancer Institute. 2016-28(2):123-7.

34. Fletcher CD, Berman JJ, Corless C, Gorstein F, Lasota J, Longley BJ, et al. Diagnosis of gastrointestinal stromal tumors: a consensus approach. Human pathology. 2002;33(5):459-65.

35. Eldamshety 0, Metwally IH, Ghoneem E, Elkashef WF. Resection of rectal GIST using a novel technique: a report of two cases. ecancermedicalscience. 2017:11.

36. Gaballa K, Metwally I, Refky B, AbdEIKhalek M, Saleh S, Abdelaziz A, et al. Ovarian gastrointestinal stromal tumor: does this diagnosis exist? EUROPEAN JOURNAL OF GYNAECOLOGICAL ONCOLOGY. 2017;38(1):147-9.

37. Joensuu H, Hohenberger P, Corless CL. Gastrointestinal stromal tumour. Lancet (London, England). 2013;382(9896):973-83.

38. Liegl B, Hornick JL, Corless CL, Fletcher CD. Monoclonal antibody DOG1. 1 shows higher sensitivity than KIT in the diagnosis of gastrointestinal stromal tumors, including unusual subtypes. The American journal of surgical pathology. 2009;33(3):437-46.

39. Langer C, Gunawan B, Schuler P, Huber W, Fuzesi L, Becker H. Prognostic factors influencing surgical management and outcome of gastrointestinal stromal tumours. The British journal of surgery. 2003;90(3):332-9.

40. Ahmed I, Welch NT, Parsons SL. Gastrointestinal stromal tumours (GIST) - 17 years experience from Mid Trent Region (United Kingdom). European journal of surgical oncology : the journal of the European Society of Surgical Oncology and the British Association of Surgical Oncology. 2008;34(4):445-9.

41. Hinz S, Pauser U, Egberts JH, Schafmayer C, Tepel J, Fandrich F. Audit of a series of 40 gastrointestinal stromal tumour cases. European journal of surgical oncology : the journal of the European Society of Surgical Oncology and the British Association of Surgical Oncology. 2006;32(10):1125-9.

42. Everett M, Gutman H. Surgical management of gastrointestinal stromal tumors: analysis of outcome with respect to surgical margins and technique. Journal of surgical oncology. 2008; 98(8):588-93.

43. Gouveia AM, Pimenta AP, Capelinha AF, de la Cruz D, Silva P, Lopes JM. Surgical margin status and prognosis of gastrointestinal stromal tumor. World journal of surgery. 2008;32(11):2375-82.

44. Cho MY, Sohn JH, Kim JM, Kim KM, Park YS, Kim WH, et al. Current trends in the epidemiological and pathological characteristics of gastrointestinal stromal tumors in Korea, 2003-2004. Journal of Korean medical science. 2010;25(6):853-62.

45. Cappellani A, Piccolo G, Cardi F, Cavallaro A, Lo Menzo E, Cavallaro $\mathrm{V}$, et al. Giant gastrointestinal stromal tumor (GIST) of the stomach cause of high bowel obstruction: surgical management. World Journal of Surgical Oncology. 2013;11:172-

46. Al-Kalaawy M, El-Zohairy MA, Mostafa A, Al-Kalaawy A, El-Sebae H. Gastrointestinal stromal tumors (GISTs), 10-year experience: Patterns of failure and prognostic factors for survival of 127 patients. Journal of the Egyptian National Cancer Institute. 2012;24(1):31-9.

47. Kassem MI, Elzeiny MM, Elhaddad HM. Management of gastrointestinal stromal tumors: a prospective and retrospective study. The Egyptian Journal of Surgery. 2016;35(1):11.

48. Salem AA, Elshoieby MH, Maximos DW, El-Saba TM. Gastrointestinal Stromal Tumors (GISTs), Surgical Management and Clinical Outcome. Journal of Cancer Therapy. 2016:7(04):319.

49. Huang $Y$, Zhao R, Cui Y, Wang Y, Xia L, Chen Y, et al. Effect of Gastrointestinal Bleeding on Gastrointestinal Stromal Tumor Patients: A Retrospective Cohort Study. Medical Science Monitor. 2018:24:363-9.

50. Amato A. Colorectal gastrointestinal stromal tumor. Techniques in coloproctology. 2010;14 Suppl 1:S91-5.

51. Liu Y-J, Yang Z, Hao L-S, Xia L, Jia Q-B, Wu X-T. Synchronous incidental gastrointestinal stromal and epithelial malignant tumors. World journal of gastroenterology: WJG. 2009;15(16):2027.

52. Liu Z, Tian Y, Xu G, Liu S, Guo M, Lian X, et al. Pancreatic Gastrointestinal Stromal Tumor. Journal of clinical gastroenterology. 2017;51(9):850-6 